\title{
Cattle tick differentiates between the odors of Holstein Friesian and Nelore cattle
}

\author{
Carrapato de bovinos diferencia o odor de bovinos da raça Holandesa e Nelore
}

Lígia Miranda Ferreira Borges ${ }^{\mathrm{I}}$ Sabrina Castilho Duarte ${ }^{\mathrm{II}}$ Carla Cristina Braz Louly ${ }^{\mathrm{II}}$

\section{- NOTE -}

\section{ABSTRACT}

\begin{abstract}
Although Rhipicephalus microplus mainly parasitizes bovines, different breeds can have variable parasite burdens, with indian breeds being less susceptible to tick infestation than european breeds. These ticks use pasture questing to seek out their hosts in the open spaces of their grassland habitats. Using an olfactometer bioassay, where the larva could express questing, the authors aimed to answer whether $\boldsymbol{R}$. microplus exhibit different behaviors depending on the bovine breed. Sixteen larvae were individually exposed to the odors of five holstein friesian cattle, five nelore cattle, hexane (negative control) and 2-nitrophenol (positive control). The highest questing responses were observed to 2-nitrophenol and holstein odors. The lowest response was observed to the solvent and was statistically similar to nelore odors. It is possible to conclude that $\boldsymbol{R}$. microplus express different questing behaviors depending on the odor of the breed perceived. This behavior can help $\boldsymbol{R}$. microplus to avoid parasitizing nelore bovines and is biologically advantageous for the tick because it is known that ticks that feed on this host have impaired development.
\end{abstract}

Key words: Rhipicephalus microplus, questing behavior, olfactometer.

\section{RESUMO}

Embora Rhipicephalus microplus parasite principalmente bovinos, diferentes raças podem ter cargas parasitárias variáveis, sendo os bovinos indianos menos suscetiveis a esse carrapato que os bovinos europeus. Este carrapato usa um comportamento de procura conhecido como questing para encontrar seu hospedeiro nas pastagens. Utilizando um teste em olfatômetro, onde a larva podia expressar o questing, objetivou-se responder se a larva podia expressar diferentes comportamentos dependendo da raça de bovino envolvida. Dezesseis larvas foram expostas para os odores de cinco bovinos holandeses, cinco nelores, hexano (controle negativo) e 2-nitrofenol (controle positivo). As mais altas respostas foram observadas para o 2-nitrofenol e odor de holandês. A mais baixa resposta foi observada para o solvente e foi estatisticamente similar ao odor de nelore. É possivel concluir que R. microplus expressa de forma diferente o comportamento de questing dependendo do odor da raça de bovinos percebido. Esse comportamento pode ajudar R. microplus a evitar parasitar bovinos nelore, o que ébiologicamente vantajoso para o carrapato, uma vez que se sabe que carrapatos alimentados neste hospedeiro têm seu desenvolvimento comprometido.

Palavras-chave: Rhipicephalus microplus, comportamento de busca, olfatômetro.

The cattle tick, Rhipicephalus microplus, is one of the most important ticks worldwide due to its high economic importance (JONSSON, 2006). This tick uses pasture questing to seek its host in the open spaces of their grassland habitats. The general behavior strategy of such ixodid ticks is to climb vegetation, spread their first pair of legs, which contain their sensory organs (haller's organ), and wait for the host. Moisture and temperature are the main factors determining the ticks' daily rhythm of climbing vegetation and descending back into leaf litter to restore lost water. The strongest stimulus for this behavior is direct contact with the host, which promotes an immediate reaction by the tick to attach with its claws (APANASKEVICH \& OLIVER, 2014).

The questing behavior of ixodid ticks serves to identify and localize approaching hosts and is evoked by carbon dioxide, vibrations, and

'Departamento de Microbiologia, Imunologia, Parasitologia e Patologia, Instituto de Patologia Tropical e Saúde Pública, Universidade Federal de Goiás (UFG), Rua 235, s/n, Setor Universitário, 74601-050, Goiânia, GO, Brasil. E-mail: borges.ligia@gmail.com. Corresponding author.

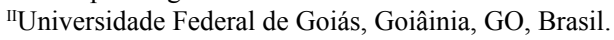

III Instituto Federal Goiano (IF Goiano), Campus Urutaí, Urutaí, GO, Brasil. 
visual and odor stimuli. Using an olfactometer, the specificity of the questing responses of $\boldsymbol{R}$. microplus larvae, a one-host tick, and Ixodes ricinus, a threehost tick with a broad host spectrum have been evaluated. Although all mammalian odors tested were equally stimulatory for $I$. ricinus, $R$. microplus was clearly more activated by bovine odors. After fractioning the bovine odor, it was observed that $\boldsymbol{R}$. microplus showed significant higher sensitivity to the cattle-associated compounds 1-octen-3-ol and 2-nitrophenol, which may contribute to its hostspecificity (OSTERKAMP, 1999).

Indian breeds (Bos taurus indicus) of cattle are less susceptible to tick infestation than taurine breeds (Bos taurus taurus) (VILLARES, 1941; WILKINSON, 1955), although it is not known if $\boldsymbol{R}$. microplus larvae can differentiate these hosts. Therefore it was developed experiments to address this question.

Engorged R. microplus females were collected on naturally infested bovines and incubated in a climatized chamber $\left(\mathrm{T}=27^{\circ} \mathrm{C}\right.$ and $\mathrm{RH}>80 \%$ ) to obtain larvae. Unfed larvae, aged 7 to 21 days, were used in the behavior tests. The odor of five holstein friesian (B. taurus taurus) and five nelore (B. taurus indicus) cattle were collected using a modification of the GIKONYO et al. (2000) technique described by LOULY et al. (2010) and stored at $-20^{\circ} \mathrm{C}$.

The behavior tests were based on OSTERCHAMPetal.(1999) with some modifications. One larvae was kept on the tip of a vertically fixed filter paper rod (4mm diameter, $150 \mathrm{~mm}$ long) within a closed glass arena $(15 \times 10.5 \times 30 \mathrm{~cm})$. The arena had two holes $(0.8 \mathrm{~cm}$ diameter $)$ on opposite sides, at the same level as the tip of the rod. A silicone tube ( $1 \mathrm{~cm}$ diameter) was connected to one hole and to a stimulus controller (Syntech, CS55, Hilversum). A constant flow of charcoal-filtered and humidified air $(>90 \%)$ was passed over the larvae. The constant flow included both a continuous $\left(\sim 15 \mathrm{ml} \mathrm{min}^{-1}\right)$ and a complimentary $\left(\sim 25 \mathrm{ml} \mathrm{min}^{-1}\right)$ air stream. Stimulation was performed by inserting the tip of the test pipette also connected to the stimulus controller into a hole in the silicone tube, which generated puffs of air $(\sim 25 \mathrm{ml}$ $\mathrm{min}^{-1}$ for $500 \mathrm{~ms}$ ) through the pipette that replaced the complimentary air stream during that time period. The experimental arena was kept at $25 \pm 3^{\circ} \mathrm{C}$ and relative humidity $>80 \%$, and a $15 \mathrm{~W}$ fluorescent lamp was placed over it. When the larvae were in a resting posture, they were subjected to one of the following stimuli: the odor of holstein cattle $(100 \mu 1)$, the odor of nelore cattle $(100 \mu \mathrm{l}), 2$-nitrophenol $(0.5 \mathrm{M}-100 \mu \mathrm{l}$ positive control) or solvent (hexane - $100 \mu \mathrm{l})$. Odor of each animal was presented randomly and always interspersed with the negative and positive controls. A total of 16 larvae were assessed, and the results were analyzed using the friedman test with a holm correction and a significance level of $\mathrm{P}<0.05$.

Only one larva failed to respond to any holstein odor evaluated, with the remainder attracted to 1 to 4 animals. Nine larvae failed to express questing behavior in response to any Nelore odor tested. The highest response was observed to 2-nitrophenol and was statistically similar to the responses observed to holstein odors. The lowest response was observed to the solvent and was statistically similar to the responses observed to nelore odors (Figure 1, Table 1).

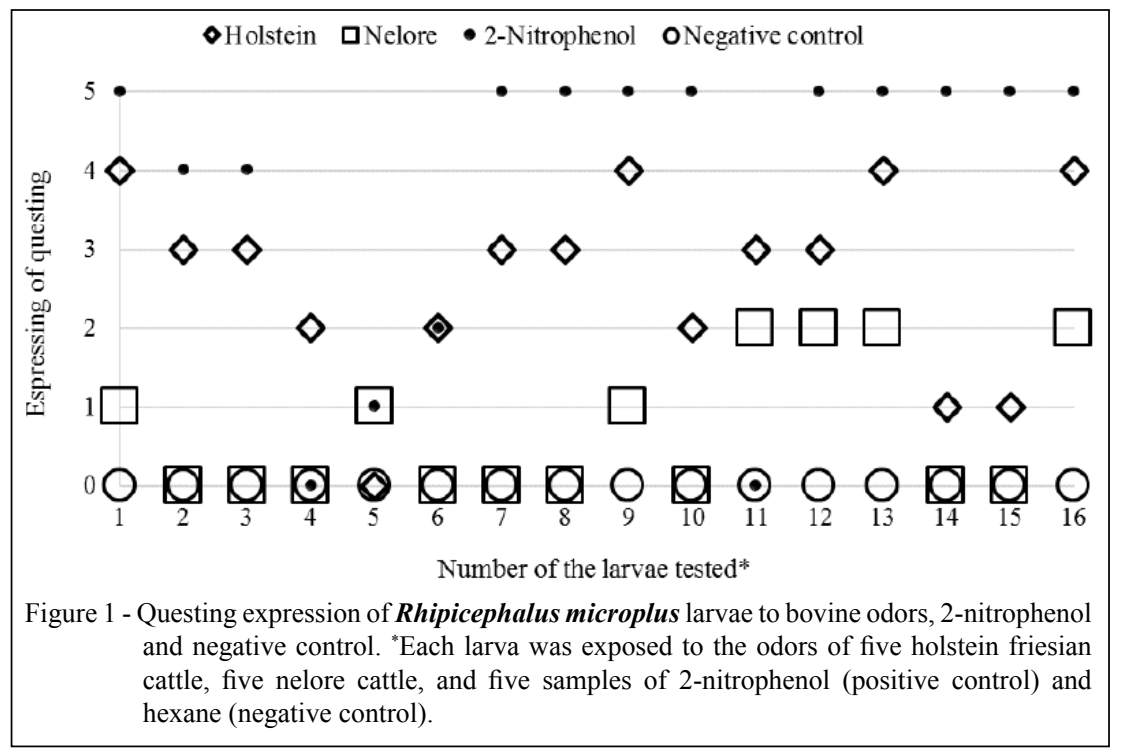

Ciência Rural, v.45, n.11, nov, 2015. 
According to APANASKEVICH \& OLIVER (2014), the height to which ticks climb depends primarily on two factors: moisture and host size. RANDOLPH (2014) proposed that the "choice" of host may be determined purely mechanistically by the tick's questing height. The two major subspecies of cattle found in grasslands, B. taurus taurus and B. taurus indicus, generally have similar sizes but are not parasitized similarly, with higher infestations found in cattle of European origin. When $\boldsymbol{R}$. microplus feeds on zebu cattle, its development is impaired; large numbers of larvae do not reach the adult stage, and the reproductive efficiency of engorged females is significantly compromised (UTECH et al., 1978). It is known that this phenomenon is, at least in part, driven by the host's immune system, but otherwise, it is unknown whether these ticks somehow differentiate their hosts before attaching. The results here found support the hypothesis that $\boldsymbol{R}$. microplus perceives the odors of nelore and holstein friesian cattle differently. The strong responses observed to 2-nitrophenol support the results obtained by ORTERKAMP et al. (1999).

Recently, FERREIRA et al. (2015) demonstrated that the cheliceral pit sensillum was more responsive to the serum of $\boldsymbol{R}$. microplusresistant bovines than to serum samples from susceptible animals. It appears that $\boldsymbol{R}$. microplus can perceive not only phagostimulants known to be present in host blood but also deterrent substances that can exist in cattle serum associated with decreased susceptibility to tick infestation. Chemoreceptors in $\boldsymbol{R}$. microplus chelicera appear to be able to distinguish serum components that differ between susceptible and resistant hosts. The present study demonstrates another $\boldsymbol{R}$. microplus mechanism used to avoid feeding on nelore cattle and the impairment of the parasite's development.

The presence of repellent semiochemicals that mediate the avoidance of the beagle dog breed by $\boldsymbol{R}$. sanguineus has already been shown

\begin{tabular}{lccc} 
Table 1 & $\begin{array}{c}\text { Friedman test after holm correction }(\mathrm{P}<0.05) \\
\text { comparing the questing expression of } \\
\text { Rhipicephalus microplus to different odors. }\end{array}$ \\
\hline Rank & Mean & Median & Holm Adjust \\
\hline 22.5 & 0.0 & 0 & $\mathrm{~b}$ \\
58.5 & 3.8 & 5 & $\mathrm{a}$ \\
49.0 & 2.6 & 3 & $\mathrm{a}$ \\
30.0 & 0.6 & 0 & $\mathrm{~b}$ \\
\hline
\end{tabular}

(OLIVEIRA FILHO, 2014). The results presented herein, however, do not allow us to distinguish whether the tick is perceiving a repellent or failing to perceive a key attractant found in nelore cattle odor. Future research will address this issue.

\section{ACKNOWLEDGEMENTS}

To the Conselho Nacional de Desenvolvimento Científico e Tecnológico (CNPq) by granting pos-doctor's scholarship to Sabrina Castilho Duarte.

\section{REFERENCES}

APANASKEVICH, D.A.; OLIVER, Jr., J.H. Life cycle and natural history of ticks. In: SONENSHINE, D.E.; ROE, M. Biology of ticks. Oxford: Oxford University, 2014. V. 1. Chap. 3, p.59-73.

FERREIRA, L.L. et al. Role of Rhipicephalus microplus cheliceral receptors in gustation and host differentiation. Tick and Tick-borne diseases, v.6, p.228-233, 2015. Available from: <http://www.sciencedirect.com/science/ article/pii/S1877959X15000023>. Accessed: May 04, 2015. doi:10.1016/j.ttbdis.2014.12.008.

GIKONYO, N.K et al. Odor composition of preferred (Buffalo and $\mathrm{Ox}$ ) and nonpreferred (Waterbuck) hosts of some savannah tsetse flies. Journal of Chemical Ecology, v.28, p.969-981, 2002. Available from: <http://link.springer.com/ article/10.1023/A\%3A1015205716921>. Accessed: May 4, 2015. doi:10.1023/A:1015205716921.

JONSSON, N.N. The productivity effects of the cattle tick (Boophilus microplus) infestation on cattle, with particular reference to Bos indicus cattle and their crosses. Veterinary Parasitology, v.137, p.1-10, 2006. Available from: $<$ http://www. sciencedirect.com/science/article/pii/S0304401706000276>. Accessed: Sept. 30, 2006. doi:10.1016/j.vetpar.2006.01.010.

Oliveira FILHO, J.G. Avaliação do papel repelente de voláteis isolados no odor de cães da raça beagle contra o carrapato Rhipicephalus sanguineus (Acari: Ixodidae). 2014. 53f. Dissertação (Mestrado em Ciência Animal) - Programa de Pós-graduação em Ciência Animal, Universidade Federal de Goiás.

OSTERKAMP, J. et al. Host-odour recognition in two tick species is coded in a blend of vertebrate volatiles. Journal of Comparative Physiology, A, v.185, p.59-67, 1999. Available from: <http://link.springer.com/article/10.1007/ s003590050366>. Accessed: May 04, 2015. doi:10.1007/ s003590050366.

RANDOLPH, S. Ecology of non-nidicolous ticks. In SONENSHINE, D.E.; ROE, M. Biology of ticks. Oxford: Oxford University, 2014. V.2. Chap.1, p.3-38.

UTECH, K.B.W. Resistance to Boophilus microplus (Canestrini) in different breeds of cattle. Australian Journal of Agricultural Research, v.29, p.885-895, 1978. Available from: <http://www.publish.csiro.au/paper/AR9780885.htm>. Accessed: May 04, 2015. doi:10.1071/AR9780885. 